\title{
DISSOLVED ORGANIC MATTER CONCENTRATION CHANGES IN RIVER WATERS OF LATVIA
}

\author{
Māris Kḷaviņš, Ilga Kokorïte, and Valērijs Rodinovs \\ Faculty of Geography and Earth Sciences, University of Latvia, Raiṇa bulv. 19, LV-1586, Rīga, LATVIA \\ E-mail: maris.klavins@lu.Iv
}

Contributed by Māris Kḷaviňš

\begin{abstract}
Amounts of natural organic matter in surface waters reflect the character and intensity of biological processes in water bodies, human impact and depend on the physico-geographical environment and land-use in the catchments. Thus, analysis of the concentrations and loadings of organic substances to adjacent water bodies can be used to indicate environmental change and human impacts. This study revealed significant increasing trends of total organic carbon (TOC) and water colour in most of the studied Latvian rivers during the last decade. However, over longer time periods, there have been pronounced oscillations of TOC concentrations, stressing the importance of long-term changes of river discharge. On a yearly basis, there was a positive correlation between parameters of organic matter concentration and discharge in all selected rivers. The impact of discharge on concentrations of organic matter can be masked by other factors, such as changes in precipitation, biological processes, soil types and land-use.
\end{abstract}

Key words: TOC, water colour, Latvia, discharge, trend analysis.

\section{INTRODUCTION}

Dissolved organic matter (characterised as total, dissolved or particulate organic carbon - TOC, DOC or POC) plays a significant role in the global carbon biogeochemical cycle, influences mineral weathering, nutrient cycling, metal leaching as well as pollutant behaviour and toxicity in waters. Organic substances accumulated in wetlands and soils are an important reserve of carbon, while human activities (extraction of peat, agricultural activities and land-use changes) and global climate change can release stored carbon both as greenhouse gases and dissolved organic substances to surface waters. Considering this, the flows of dissolved organic matter are very important indicators of climate change. Flows of organic substances are influenced by the proportion of area covered by wetlands in the catchment, intensity of eutrophication, bedrock geology, intensity of agricultural land-use, direct anthropogenic load (also, industrial effluents and non-point pollution sources) and other features of the catchment area, and thus, their character evidently depends on the studied region (Gergel et al., 1999).

Internationally, the roles of dissolved organic matter in the global biogeochemical carbon cycle, on biological processes in hydroecosystems, in reduction of pollutant toxicity and flows of DOC have been investigated (Depetris and Kempe, 1993; Pettine et al., 1998; Westerhoff and Anning, 2000; Arvola et al., 2004; Evans et al., 2005). However, the observed organic matter trends are quite contradictory; most studies show increasing DOC trends (Evans et al., 2005; Roulet and Moore, 2006; Vuorenmaa et al., 2006), but significant decreasing trends have also been found (Arvola et al. 2004). Clair et al. (2008) found a significant decreasing trend of TOC concentrations during the 1980s, when acid deposition was decreasing rapidly, there were no significant changes in TOC concentrations during 1995-2005. Increasing DOC concentrations can be explained by global climate change, such as decrease of acid precipitation or sea salt deposition (Hongve et al., 2004) and increased atmospheric temperature, which in turn leads to a higher microbial degradation rate of organic matter (Fenner et al., 2007; Xiang and Freeman, 2009). Results from experimental studies (Freeman et al., 2004; Fenner et al., 2007; Hagedorn and Machwitz, 2007) support the hypothesis that elevated atmospheric $\mathrm{CO}_{2}$ concentrations, along with increasing temperatures, can enhance DOC export from catchments due to increased primary production and DOC exudation from decaying plants, as well as due to changes in the composition of organic matter. Changes in hydrological regime such as increased discharge and changes of flow-path, and drought, also have an impact on concentrations and fluxes of dissolved organic carbon from catchments (Clark et al., 2008; Dawson et al., 2008; Jager et al., 2009). Worrall and Burt (2007) examined long-term data on DOC concentrations from 315 monitoring stations in Great Britain and found that, despite dominant increasing trends, DOC concentrations in some rivers in the south-west of the country 
showed a significant decreasing trend. This indicates the importance of region or even catchment-specific processes, e.g. land-use types, anthropogenic pressure and hydrological features (Worrall and Burt, 2007; Mattsson et al., 2009; Yallop and Clutterbuck, 2009). In previous studies of dissolved organic matter in Latvia (during 1977-1995), significant decreasing trends of chemical oxygen demand and water colour were found and explained by decreasing anthropogenic load in catchments (Apsite and Klavins, 1997). In the last decades, the environmental situation in Latvia has been connected with evident climate change phenomena, which raises the question of trends of organic carbon and their influencing factors.

The aim of this study was to analyse long-term changes of concentration and loadings of organic matter in river waters of Latvia and the controlling factors.

\section{MATERIALS AND METHODS}

The study site covers the entire territory of Latvia (Fig. 1). Latvia, with an area of $64000 \mathrm{~km}^{2}$, is located on the northwestern part of the East European Plain on the coast of the Baltic Sea. Bedrock is covered by Quaternary deposits consisting of moraine material, limnoglacial or fluvioglacial deposits. The climatic conditions can be characterised as humid with mean annual precipitation of $600-850 \mathrm{~mm}$ (Klavins et al., 2002). Due to the influence of cyclones, summer temperatures are slightly lower, but winter temperatures are higher than the average for temperate zones. The mean temperature in January varies from $-2.6{ }^{\circ} \mathrm{C}$ to $-6.6{ }^{\circ} \mathrm{C}$, and in July from $+16.8{ }^{\circ} \mathrm{C}$ to $+17.6{ }^{\circ} \mathrm{C}$. The rivers in Latvia have mixed water feeding: rain, snowmelt and groundwater. The river discharge in spring is $45-55 \%$ of the total annual discharge, and winter contributes only 15-20\% of annual discharge (Klavins et al., 2002).

It has been shown that DOC constitutes $95 \%$ of the TOC on average for surface waters, and thus the TOC values are equivalent to DOC (Vuorenmaa et al., 2006). Data on chemical oxygen demand (COD) (after 2003, TOC is used), water colour, parameters of basic water chemistry and river discharge used in this study were obtained from the Latvian Environment, Geology and Meteorology Centre for the period 1977-2005. Water colour was determined colorimetrically until 1995, but after 1995 spectrophotometrically using the $\mathrm{Pt} / \mathrm{Co}$ scale. COD was determined by oxidation with $\mathrm{K}_{2} \mathrm{Cr}_{2} \mathrm{O}_{7}$ and titration with ferrous ammonium sulphate (Anonymous, 1973). At the studied sites, the discharge, temperature and basic chemistry were also measured. Commencing in 2002, COD measurements were replaced by TOC measurements. For one year (2003), COD and TOC measurements were run in parallel in all monitoring stations. Since 2003, TOC was measured using a Shimadzu Total Organic Carbon Analyser TOC $-\mathrm{V}_{\mathrm{CSN}}$. The relationship between COD and TOC was estimated using a calibration experiment indicating the following relationship between recorded COD and TOC:

TOC $=(0.2928 \times \mathrm{COD})+7.9503 ; \mathrm{r}^{2}=0.611, P<0.05$

A similar approach has been used in other studies (e.g. Hejzlar et al., 2003; Worrall et al., 2003; Worall and Burt, 2007; Erlandsson et al., 2008) to calculate DOC or TOC values from historical data of water colour, $\mathrm{COD}_{\mathrm{Mn}}$ or $\mathrm{COD}_{\mathrm{Cr}}$.

Long-term changes in river discharge, TOC and water colour were studied using the non-parametric Mann-Kendall test (Hirsh et al., 1982; Hirsh and Slack, 1984), which can be applied to data sets with non-normal distributions, missing values or "outliers", and serial character (e.g. seasonal changes). The programme MULTIMK/CONDMK was used to detect trends, as it allowed including covariates representing natural fluctuations (e.g. meteorological and hydrological data; Libiseller and Grimvall, 2002). A Mann-Kendall test value $>1.96$ indicates $P<0.05$; and $<-1.96$ indicates an increasing trend $(P<0.05)$. The Mann-Kendall test was applied to the period 1996-2005, as for this period water colour was measured by uniform methods. This avoided the effect of different analytical methods on the study results.

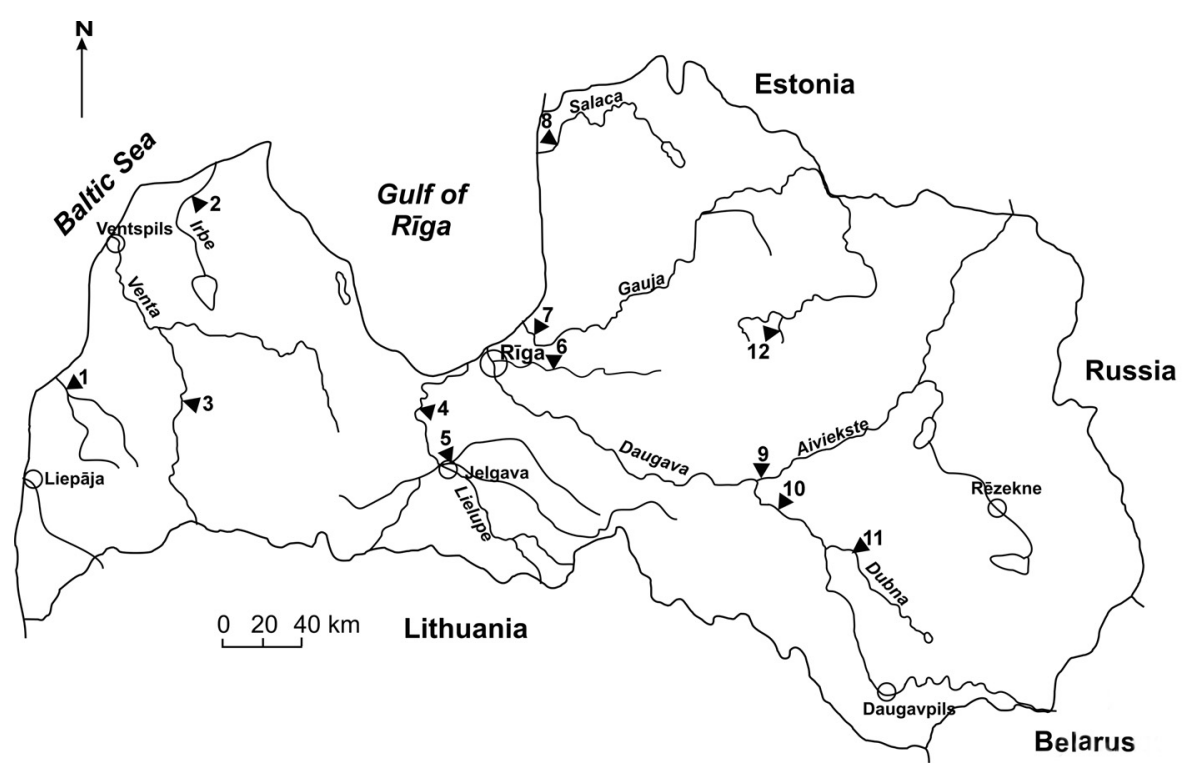

Fig. 1. Location of monitoring sites ( $\mathbf{\nabla})$ : 1 the River Tebra $1.5 \mathrm{~km}$ upstream the Town Aizpute; 2 - the River Irbe at hydrological station Vičaki; 3 - the River Venta $0.5 \mathrm{~km}$ upstream the Town Kuldiga; 4 - the Lielupe River $0.5 \mathrm{~km}$ upstream the Town Kalnciems; 5 - the River Iecava at the river mouth; 6 the River Lielā Jugla $0.2 \mathrm{~km}$ upstream the Village Zaki; 7 - the River Gauja 2 km downstream the Village Carnikava; 8 - the River Salaca $0.5 \mathrm{~km}$ upstream the Town Salacgrīva; 9 - the River Aiviekste $0.2 \mathrm{~km}$ upstream the river mouth; 10 - the River Daugava $1.0 \mathrm{~km}$ upstream the Town Jēkabpils; 11 - the River Dubna $2.5 \mathrm{~km}$ upstream the Town Līvāni; 12 - the River Tulija $0.3 \mathrm{~km}$ downstream the Village Zosēni. 
CHARACTERISTICS OF THE STUDIED RIVER BASINS FROM UPSTREAM MONITORING STATIONS ${ }^{1}$

\begin{tabular}{|c|c|c|c|c|c|c|c|c|c|}
\hline \multirow{2}{*}{$\begin{array}{c}\text { No. of } \\
\text { sampling } \\
\text { station }^{2} \\
\end{array}$} & \multirow[t]{2}{*}{ River } & \multirow{2}{*}{$\begin{array}{c}\text { Catchment area, } \\
\mathrm{km}^{2}\end{array}$} & \multirow{2}{*}{$\begin{array}{c}\text { River length, } \\
\text { km }\end{array}$} & \multirow{2}{*}{$\begin{array}{c}\text { Mean long-term } \\
\text { discharge, } \\
\mathrm{m}^{3} \mathrm{~s}^{-1}\end{array}$} & \multirow{2}{*}{$\begin{array}{c}\text { Population } \\
\text { density, } \\
\text { inh. } \mathrm{km}^{-2}\end{array}$} & \multicolumn{4}{|c|}{ Land-use, \% } \\
\hline & & & & & & urban & wetland & forest & agri-culture \\
\hline 1 & Tebra & 71.2 & 21 & 1.37 & 20.01 & 0.25 & 0.39 & 59.76 & 37.27 \\
\hline 2 & Irbe & 1920 & 4 & 16.2 & 15.62 & 0.95 & 2.94 & 73.13 & 19.84 \\
\hline 3 & Venta & 8321 & 254 & 65.47 & 17.43 & 0.85 & 0.92 & 51.75 & 45.66 \\
\hline 4 & Lielupe & 16426 & 90 & 97.6 & 31.43 & 0.84 & 1.28 & 43.95 & 53.37 \\
\hline 5 & Iecava & 998 & 155 & 7.22 & 36.97 & 1.07 & 1.92 & 59.63 & 36.72 \\
\hline 6 & Lielā Jugla & 663 & 45 & 6.31 & 25.61 & 0.44 & 2.49 & 58.68 & 38.19 \\
\hline 7 & Gauja & 8890 & 438 & 73.95 & 20.82 & 0.86 & 1.43 & 58.99 & 37.86 \\
\hline 8 & Salaca & 3471 & 92 & 21.56 & 12.49 & 0.37 & 4.04 & 55.98 & 37.63 \\
\hline 9 & Aiviekste & 9140 & 111 & 60.98 & 19.83 & 0.72 & 3 & 45.73 & 47.72 \\
\hline 10 & Daugava & 72182 & 843 & 517 & 30.98 & 1.19 & 3.05 & 38.25 & 54.28 \\
\hline 11 & Dubna & 2462 & 125 & 16.49 & 15.25 & 0.74 & 4.7 & 31.16 & 59.79 \\
\hline 12 & Tulija & 33.4 & 12 & 0.34 & 13.82 & 0 & 0 & 47.33 & 52.67 \\
\hline
\end{tabular}

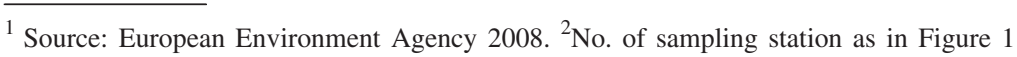

\section{RESULTS}

TOC concentrations in surface waters of Latvia were comparatively high and were associated with the land-use character in the river catchments (Table 1), abundance of wetlands, degree of eutrophication of lakes, surface leakage of soil humus (more intensive during spring and autumn floods), and impact of wastewater (Fig. 2). Mean values of TOC concentrations varied from $15 \mathrm{mg} / \mathrm{l}$ in rivers Tebra and Venta of the western part of the country; to $19 \mathrm{mg} / \mathrm{l}$ in rivers Lielupe, Dubna and Aiviekste; and $21 \mathrm{mg} / \mathrm{l}$ in the River Iecava (Fig. 2). A special group of waterbodies include rivers receiving their waters directly from wetlands: water colour in such rivers can be brownish, and TOC values can reach even 50-70 mg/l (Fig. 2).

There were significant annual and long-term changes in the concentration and discharge of organic matter in rivers of
Latvia (Fig. 3 and 4), and TOC values were associated with water colour. For example, in waters of River Salaca there was an increase in water colour (concentration of colored dissolved organic substances) during the last few decades (Fig. 4) - the brownification of water - a phenomenon known in other European countries and elsewhere (Worrall et al., 2003; Hongve et al., 2004; Roulet and Moore, 2006; Worrall and Burt, 2007). During the period of increased water color, human impact (agricultural activities and urban development) was relatively stable, also considering the status of the protected area in the study region.

Trends of changes of organic matter concentration indicators (TOC and colour) were evidently greatly influenced by changes in river discharge regime. When the Mann-Kendall test was applied to selected rivers to estimate the influence of discharge on monotonic long-term trends of TOC and water colour (Fig. 5) the test statistic values were valid and

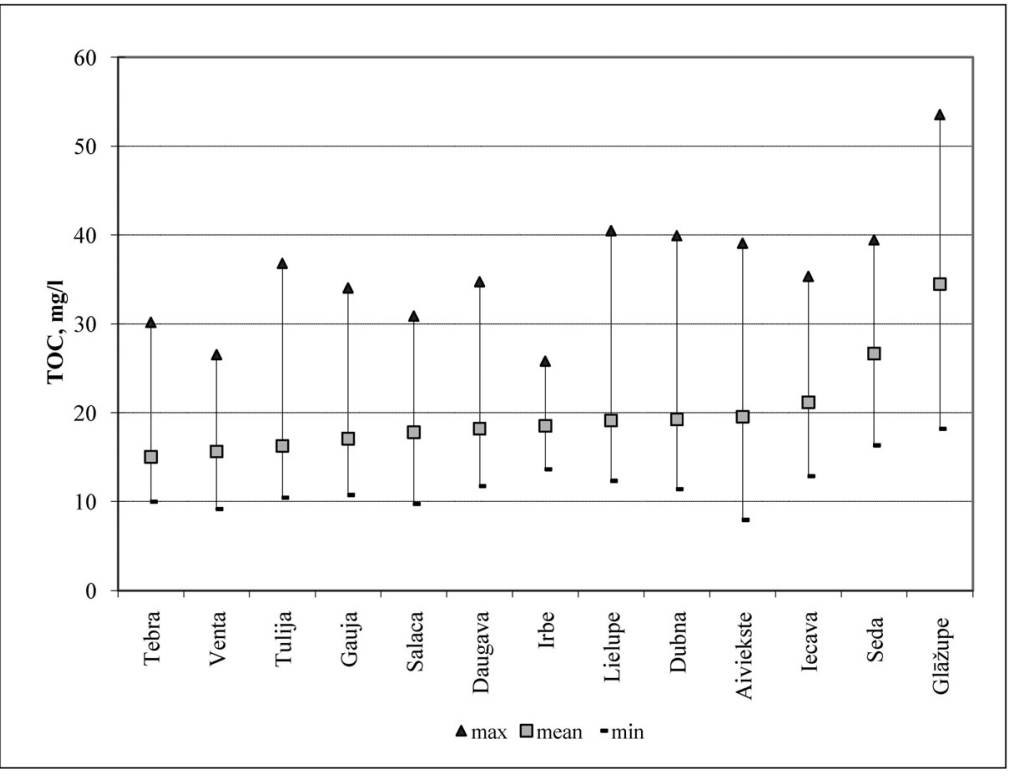

Fig. 2. Variability of TOC concentration $(\mathrm{mg} / \mathrm{l})$ in river waters of Latvia (1977-2008) 

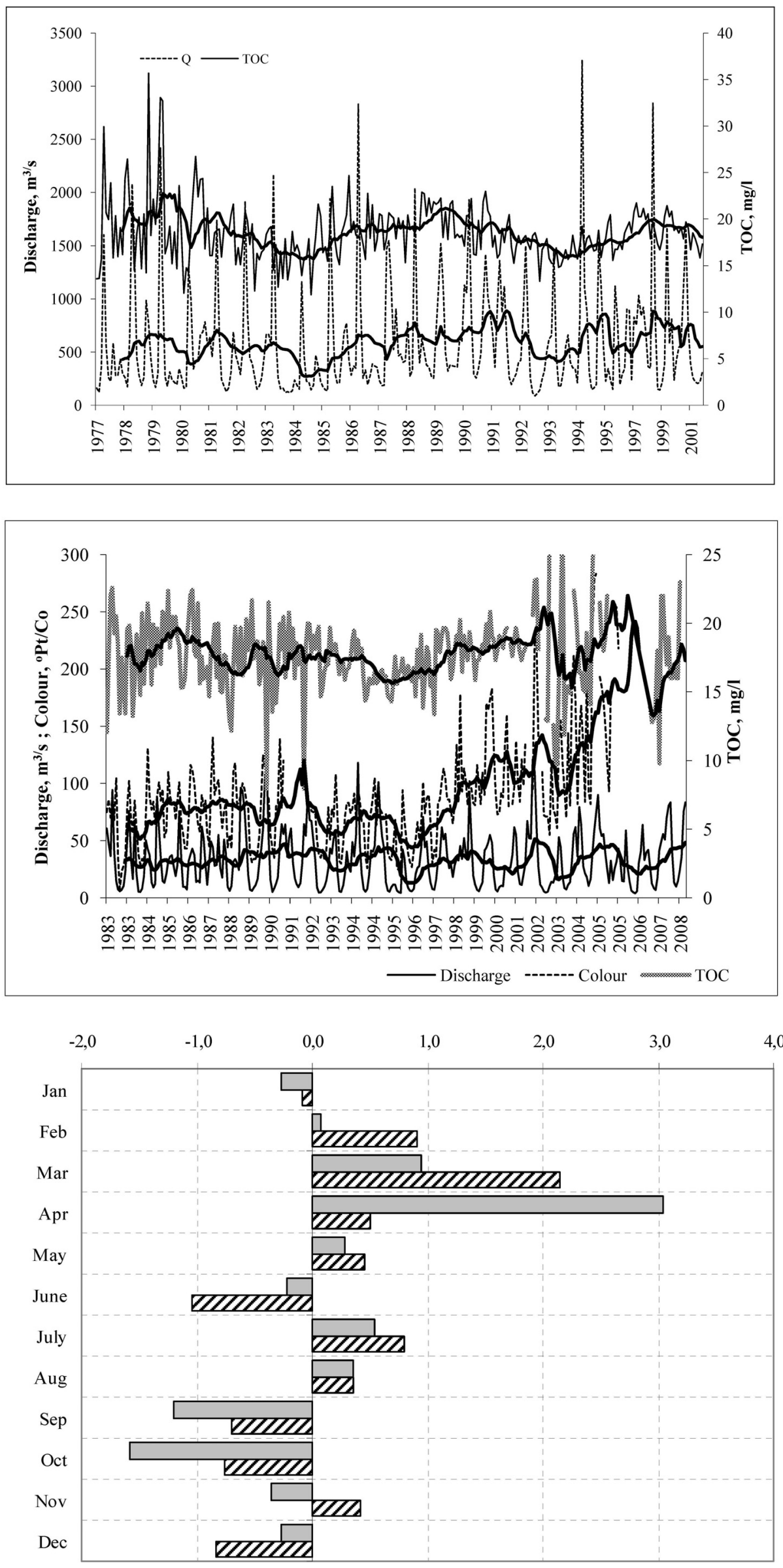

$\square$ Daugava R. שVenta R.
Fig. 3. Long-term (1977-2002) changes of the River Daugava discharge and TOC concentrations in river water (data were smoothed with a 12-month moving average)

Fig. 4. Long-term (1983-2008) changes of River Salaca discharge, TOC concentrations and water colour in river water (data were smoothed with a 12-month moving average)

Fig. 5. Mann-Kendall test statistics of seasonal changes of TOC concentration in the Rivers Daugava and Venta (1983-2008) 
relatively robust in respect to fluctuations of discharge intensity.

Trends of changes of organic matter concentration (TOC) were highly variable within a year and had strong seasonal character (Fig. 5). Major increases in TOC occurred in late winter-spring (February-April/May), which were associated with spring floods. There were no statistically significant long-term trends of concentrations of TOC in other seasons. However, at the end of summer and early autumn (August-September) TOC values had a weak decreasing trend.

An important indicator of the processes occurring in the river basins is organic matter (TOC) export (Table 2). The TOC export values for river basins in Latvia, which ranged from $1800 \mathrm{~kg} / \mathrm{km}^{2}$ per year to $31001800 \mathrm{~kg} / \mathrm{km}^{2}$ per year, evidently depended on the character of land-use and aquatic chemistry in the river basins.

\section{DISCUSSION}

Spatial and seasonal variability of concentrations of organic substances in surface waters of Latvia were comparatively high. The larger proportion of wetlands (Table 1) in the Rivers Aiviekste (3\%) and Dubna (4.7\%) caused higher TOC concentrations in waters of these rivers. However, in small streams where the proportion of wetlands was as high as $\sim 90 \%$, the corresponding TOC values were extremely high, causing really brown colour of waters. Agricultural areas within the river basin can be a source of increased organic carbon concentrations in surface waters of Latvia (Table 1). Population density in Latvia (particularly compared with Western European countries) is low and the largest cities are located in the vicinity of river mouths. Thus, it might be expected that the impact of direct human loading on TOC concentrations is comparatively low. The TOC values observed in our study were comparable to measured TOC concentrations in other catchments of boreal and temperate zones. For example, in Finnish rivers average TOC concentrations were estimated to be 5-21 mg/l (Mattsson et al., 2005), and in some rivers in Canada, 7.5-17.7 mg/l (Clair et al., 2008).

In the studied rivers, TOC concentrations were associated with river discharge (Fig. 3). Thus, it can be hypothesised that river discharge is a major factor driving long-term changes of TOC concentration. Periodic oscillations of long-term river discharge are common for Latvian rivers and the main frequency of changes of high and low water periods is estimated to be about from 27 to 30 years (Klavins and Rodinov, 2008) and thus also TOC changes can have the same pattern. Similar trends have been observed previously: Erlandsson et al. (2008) observed oscillating patterns of long-term changes of chemical oxygen demand (the total length of COD records was 35 years) and discharge in large river basins in Sweden.

Mann-Kendall tests were applied to detect linear changes of TOC, water colour and parameters of basic aquatic chemis-
Table 2

TOTAL ORGANIC CARBON (TOC) EXPORT VALUES FROM RIVER BASINS OF LATVIA

\begin{tabular}{lc}
\hline \multicolumn{1}{c}{ River } & TOC, $\mathrm{kg} / \mathrm{km}^{2}$ year \\
\hline \multicolumn{2}{c}{ Large rivers } \\
Salaca & 3050 \\
Gauja & 2182 \\
Daugava & 2848 \\
Lielupe & 2419 \\
Venta & 2414 \\
\multicolumn{1}{c}{ Medium and small rivers } \\
Dubna & 2370 \\
Aiviekste & 2820 \\
Rēzekne & 1800 \\
Lielā Jugla & 2680 \\
Mēmele & 2713 \\
Iecava & 2790 \\
Misa & 2740 \\
Svēte & 1870 \\
Bērze & 2189 \\
Abava & 2410 \\
Saka & 2080 \\
Irbe & 2660 \\
Bārta & 2190
\end{tabular}

try during recent decades. All significant trends of TOC and water colour values $(P<0.05$ and $P<0.1)$ showed an increasing trend (Table 3 ). Interestingly, there were no significant changes of TOC concentrations for rivers with large catchment areas (rivers Gauja, Daugava, Lielupe and Venta). Despite the good correlation between TOC and water colour (Table 4), there were some differences between trends of changes of TOC concentration and water colour (Table 3). Water colour had a pronounced trend in 7 of 11 studied rivers, indicating that concentrations of coloured dissolved organic matter increased significantly; however, TOC significantly increased in three of the studied rivers. Thus, in river waters of Latvia, only the coloured part of organic matter likely increases, and not the total concentration of organic matter estimated by TOC. Nutrient concentrations, as well as bicarbonate and sodium ion concentrations did not show pronounced trends (except for bicarbonate in the River Daugava). Concentrations of sulphate and magnesium ions show a decreasing trend for the study period 1996-2005.

Hongve et al. (2004) observed increases of water colour and acidity, but no significant changes of DOC concentrations in lakes in southern Norway. Researchers have proposed that changing hydrological regime and flow-paths can alter chemical properties of organic matter, e.g. increased precipitation can flush out from upper soil horizons more coloured and acidic organic compounds with higher molecular weight (Hongve et al., 2004). The differences in trends of TOC and colour in the present study may also be related to increased atmospheric precipitation in Latvia (Reihan et al., 2007; Jaagus et al., in press). 
LONG-TERM (1996-2005) MANN-KENDALL TEST STATISTICS OF WATER CHEMICAL COMPOSITION ${ }^{1}$

\begin{tabular}{|c|c|c|c|c|c|c|c|c|}
\hline $\begin{array}{c}\text { Monitoring } \\
\text { station }\end{array}$ & TOC & Colour & $\mathrm{N}-\mathrm{NO}_{3}^{-}$ & $\mathrm{P}-\mathrm{PO}_{4}{ }^{3-}$ & $\mathrm{HCO}_{3}^{-}$ & $\mathrm{SO}_{4}{ }^{2-}$ & $\mathrm{Mg}^{2+}$ & $\mathrm{Na}^{+}$ \\
\hline Salaca & $\begin{array}{c}2.56 \\
N=81\end{array}$ & $\begin{array}{c}2.90 \\
N=109\end{array}$ & $\begin{array}{c}-0.83 \\
N=109\end{array}$ & $\begin{array}{c}-0.51 \\
N=107\end{array}$ & $\begin{array}{c}-0.54 \\
N=83\end{array}$ & $\begin{array}{c}-\mathbf{2 . 6 1} \\
N=83\end{array}$ & $\begin{array}{c}-1.36 \\
N=83\end{array}$ & $\begin{array}{c}-0.38 \\
N=85\end{array}$ \\
\hline Gauja & $\begin{array}{c}-0.06 \\
N=82\end{array}$ & $\begin{array}{c}\mathbf{1 . 9 7} \\
\mathrm{N}=111\end{array}$ & $\begin{array}{c}-1.20 \\
N=111\end{array}$ & $\begin{array}{c}-0.30 \\
N=111\end{array}$ & $\begin{array}{c}-0.39 \\
N=92\end{array}$ & $\begin{array}{c}-\mathbf{3 . 0 2} \\
N=92\end{array}$ & $\begin{array}{c}-\mathbf{2 . 1 9} \\
N=92\end{array}$ & $\begin{array}{c}0.67 \\
N=92\end{array}$ \\
\hline Daugava & $\begin{array}{c}0.87 \\
N=50\end{array}$ & $\begin{array}{c}2.41 \\
N=74\end{array}$ & $\begin{array}{c}0.11 \\
N=74\end{array}$ & $\begin{array}{c}0.26 \\
N=74\end{array}$ & $\begin{array}{c}2.06 \\
N=63\end{array}$ & $\begin{array}{c}-1.99 \\
N=63\end{array}$ & $\begin{array}{c}0.54 \\
N=63\end{array}$ & $\begin{array}{c}1.50 \\
N=63\end{array}$ \\
\hline Aiviekste & $\begin{array}{c}1.88 \\
\mathrm{~N}=47\end{array}$ & $\begin{array}{c}2.42 \\
N=71\end{array}$ & $\begin{array}{c}0.55 \\
N=71\end{array}$ & $\begin{array}{c}-1.63 \\
N=71\end{array}$ & $\begin{array}{c}1.14 \\
\mathrm{~N}=45\end{array}$ & $\begin{array}{c}-1.42 \\
N=45\end{array}$ & $\begin{array}{c}-1.09 \\
N=45\end{array}$ & $\begin{array}{l}-1.28 \\
N=45\end{array}$ \\
\hline Dubna & $\begin{array}{c}2.28 \\
N=47\end{array}$ & $\begin{array}{c}1.53 \\
N=71\end{array}$ & $\begin{array}{c}-1.29 \\
\mathrm{~N}=71\end{array}$ & $\begin{array}{c}-0.23 \\
N=71\end{array}$ & $\begin{array}{c}1.27 \\
\mathrm{~N}=45\end{array}$ & $\begin{array}{c}-1.72 \\
N=45\end{array}$ & $\begin{array}{c}-1.71 \\
\mathrm{~N}=45\end{array}$ & $\begin{array}{c}-0.90 \\
N=45\end{array}$ \\
\hline Lielā Jugla & $\begin{array}{c}1.28 \\
N=94\end{array}$ & $\begin{array}{c}2.69 \\
N=94\end{array}$ & $\begin{array}{c}-1.33 \\
N=94\end{array}$ & $\begin{array}{c}-1.34 \\
N=94\end{array}$ & $\begin{array}{c}0.07 \\
\mathrm{~N}=94\end{array}$ & $\begin{array}{c}\mathbf{- 2 . 7 6} \\
N=94\end{array}$ & $\begin{array}{c}-\mathbf{2 . 0 0} \\
N=94\end{array}$ & $\begin{array}{c}-1.50 \\
N=94\end{array}$ \\
\hline Lielupe & $\begin{array}{c}1.51 \\
\mathrm{~N}=81\end{array}$ & $\begin{array}{c}\mathbf{2 . 6 5} \\
N=111\end{array}$ & $\begin{array}{c}-0.39 \\
\mathrm{~N}=110\end{array}$ & $\begin{array}{c}-1.48 \\
N=111\end{array}$ & $\begin{array}{c}-0.13 \\
N=87\end{array}$ & $\begin{array}{c}-1.83 \\
\mathrm{~N}=86\end{array}$ & $\begin{array}{c}-2.20 \\
N=87\end{array}$ & $\begin{array}{c}-1.59 \\
N=87\end{array}$ \\
\hline Iecava & $\begin{array}{c}2.19 \\
N=49\end{array}$ & $\begin{array}{c}1.61 \\
N=77\end{array}$ & $\begin{array}{c}-0.04 \\
N=77\end{array}$ & $\begin{array}{c}1.17 \\
N=76\end{array}$ & $\begin{array}{c}-1.24 \\
N=26\end{array}$ & $\begin{array}{c}-1.61 \\
N=18\end{array}$ & $\begin{array}{c}-1.64 \\
N=26\end{array}$ & $\begin{array}{c}-0.47 \\
N=26\end{array}$ \\
\hline Venta & $\begin{array}{c}1.38 \\
N=64\end{array}$ & $\begin{array}{c}0.89 \\
N=91\end{array}$ & $\begin{array}{c}-0.73 \\
N=91\end{array}$ & $\begin{array}{c}\mathbf{- 1 . 9 7} \\
N=91\end{array}$ & $\begin{array}{c}1.62 \\
N=74\end{array}$ & $\begin{array}{c}-\mathbf{2 . 4 2} \\
\mathrm{N}=74\end{array}$ & $\begin{array}{c}\mathbf{- 1 . 8 1} \\
N=74\end{array}$ & $\begin{array}{c}0.48 \\
\mathrm{~N}=74\end{array}$ \\
\hline Irbe & $\begin{array}{c}1.93 \\
\mathrm{~N}=64\end{array}$ & $\begin{array}{c}\mathbf{2 . 5 6} \\
N=93\end{array}$ & $\begin{array}{c}\mathbf{- 2 . 0 7} \\
N=93\end{array}$ & $\begin{array}{c}-0.46 \\
N=93\end{array}$ & $\begin{array}{c}1.26 \\
N=84\end{array}$ & $\begin{array}{c}-3.12 \\
N=84\end{array}$ & $\begin{array}{c}0.03 \\
\mathrm{~N}=84\end{array}$ & $\begin{array}{c}0.40 \\
N=84\end{array}$ \\
\hline Tebra & $\begin{array}{c}1.34 \\
N=45\end{array}$ & $\begin{array}{c}-0.12 \\
N=72\end{array}$ & $\begin{array}{c}-0.93 \\
N=70\end{array}$ & $\begin{array}{c}-1.64 \\
N=72\end{array}$ & $\begin{array}{c}-1.73 \\
\mathrm{~N}=18\end{array}$ & $\begin{array}{c}0.26 \\
N=18\end{array}$ & $\begin{array}{c}-1.85 \\
\mathrm{~N}=18\end{array}$ & $\begin{array}{c}-0.52 \\
N=18\end{array}$ \\
\hline
\end{tabular}

$\overline{\mathrm{N}}$ - number of observation; in bold $-P<0.05$; italic $-P<0.1 .{ }^{1}$ TOC changes are analysed for period 1996-2003

Table 4

SPEARMAN'S RHO CORRELATION BETWEEN DISCHARGE AND TOC AND WATER COLOUR IN DIFFERENT SEASONS (1996-2008)

\begin{tabular}{|c|c|c|c|}
\hline & River & TOC & Colour \\
\hline \multicolumn{4}{|c|}{ Winter } \\
\hline Daugava & & $0.879 * * \mathrm{~N}=12$ & $0.708 * * \mathrm{~N}=17$ \\
\hline Salaca & & $0.664 * * N=20$ & $0.653 * * \mathrm{~N}=27$ \\
\hline Venta & & $0.354 \mathrm{~N}=17$ & $0.460 * \mathrm{~N}=22$ \\
\hline Gauja & & $0.541 * \mathrm{~N}=27$ & $0.620 * * \mathrm{~N}=27$ \\
\hline \multicolumn{4}{|c|}{ Spring } \\
\hline Daugava & & $0.096 \mathrm{~N}=16$ & $0.158 \mathrm{~N}=24$ \\
\hline Salaca & & $0.445 * \mathrm{~N}=21$ & $0.578 * * \mathrm{~N}=30$ \\
\hline Venta & & $0.382 \mathrm{~N}=18$ & $0.501 * * \mathrm{~N}=27$ \\
\hline Gauja & & $0.691 * * N=21$ & $0.492 * * \mathrm{~N}=30$ \\
\hline \multicolumn{4}{|c|}{ Summer } \\
\hline Daugava & & $0.519 \mathrm{~N}=11$ & $0.371 \mathrm{~N}=19$ \\
\hline Salaca & & $-0.076 \mathrm{~N}=22$ & $0.362 * \mathrm{~N}=30$ \\
\hline Venta & & $0.722 * * N=16$ & $0.487 * \mathrm{~N}=24$ \\
\hline Gauja & & $0.821 * * \mathrm{~N}=22$ & $0.617 * * \mathrm{~N}=30$ \\
\hline \multicolumn{4}{|c|}{ Autumn } \\
\hline Daugava & & $0.900 * * \mathrm{~N}=12$ & $0.716 * * \mathrm{~N}=19$ \\
\hline Salaca & & $0.691 * * N=21$ & $0.659 * * \mathrm{~N}=27$ \\
\hline Venta & & $0.657 * \mathrm{~N}=14$ & $0.564 * \mathrm{~N}=19$ \\
\hline Gauja & & $0.759 * * \mathrm{~N}=21$ & $0.677 * * \mathrm{~N}=27$ \\
\hline
\end{tabular}

To explain changes in organic matter concentration, it is important to consider also trends of changes of acidity (and sulphate and chloride ion concentrations) in atmospheric precipitation (Clair et al., 2008). In Latvia, monitoring data has indicated decreasing concentrations of sulphate and magnesium ions (possible origin is weathering of dolomites - an abundant mineral in Latvia — due to acidic precipitation) in river waters, and these trends may be related to decreased acidity of precipitation in recent decades (Terauda and Nikodemus, 2007). Thus, it is highly possible that changes in organic matter concentrations in waters of Latvia were also influenced by changes in acidity of precipitation.

Balance between allochtonous and autochtonous processes and differing organic matter sources influence seasonal changes of TOC concentration. The highest TOC concentrations were in spring during snowmelt and in late autumn (Fig. 7, Table 4). Correlations between river discharge and TOC and colour were the strongest in autumn. In spring these correlations were slightly weaker, perhaps due to a dilution effect from snowmelt. Relatively weaker links between discharge and TOC and colour were common for summer when the intensity of biological processes was greatest.

On a yearly basis, there were high positive correlations between parameters of dissolved organic matter and discharge in all of the studied rivers $\left(\mathrm{r}_{\mathrm{S}}=0.540-0.803 ; P<0.01\right)$; 
however, correlation on a yearly basis was lower than the seasonal correlation. There were only weak negative correlations between parameters of organic matter and water temperature, both in the whole data sets and when split into seasonal data. In contrast to the observations of Erlandsson et al. (2008), who found concentration of $\mathrm{SO}_{4}{ }^{2-}$ to be an important predictor of dissolved organic matter, our data revealed only weak correlations $\left(\mathrm{r}_{\mathrm{S}}=-0.13\right.$ to -0.49$)$; however, there were strong negative correlations with $\mathrm{Cl}^{-}, \mathrm{Na}^{+}$ and $\mathrm{HCO}_{3}^{-}$(Table 4).

Changes in TOC seemed coupled to oscillating patterns of long-term changes of river discharge (Figs. 3 and 4), suggesting that natural processes play a significant role in actual flows of organic matter. For example, changes in the hydrological regime and climate can influence both production and leaching of organic matter at levels exceeding the impact of human loading. Typically, there was a positive relationship between organic matter content and river discharge. The present study revealed a close correlation between river discharge and TOC as well as colour. Thus, the linear trend analysis of organic matter concentration changes did not adequately reveal the character of processes influencing production and decay of organic substances in the aquatic and adjacent environments and factors controlling these processes. River discharge is a major factor influencing water colour and TOC; however, climate change also affects organic matter flows via effects on the discharge regime.

There are evidently a multitude of factors affecting concentrations of organic substances in waters, and especially in large river basins. Impact of water discharge on concentrations of dissolved organic matter can be masked by complex factors, including long water flow paths, different land-use types, soil types and climate.

Concentrations of dissolved organic substances, indicated by water colour and total organic carbon concentrations, in surface waters of Latvia had high spatial and temporal variability. Concentrations of TOC and values of water colour had an increasing trend during the last decade. River discharge is a major factor influencing dissolved organic substances; however, processes influencing organic matter production and decay determine the seasonal variability of changes. Other factors that possibly affect concentrations of organic substances are changes in acidity of atmospheric precipitation, and human loading intensity during recent decades.

\section{REFERENCES}

Anonymous (1973). Standard Methods for Chemical Analysis of Surface Waters. Leningrad: Gidromeoizdat (in Russian).

Apsite, E., Klavins, M. (1998). Assessment of the changes of COD and color in rivers of Latvia during the last twenty years. Environ. Internat., 24(5/6), 637-643.

Arvola, L., Räike, A., Kortelainen, P., Järvinen, M. (2004). The effect of climate and landuse on TOC concentrations and loads in Finnish rivers. Boreal Environ. Res., 9, 381-387.
Clair, T.A., Dennis, I.F., Vet, R., Laudon, H. (2008). Long-term trends in catchment organic carbon and nitrogen exports from three acidified catchments in Nova Scotia, Canada. Biogeochemistry, 87, 83-97.

Clark, J.M., Lane, S.N., Chapman, P.J., Adamson, J.K. (2008). Lind between DOC in near surface peat and stream water in an upland catchment. Sci. Total Environ., 404, 308-315.

Dawson, J.J.C., Soulsby, C., Tetzlaff, D., Hrachowitz, M., Dunn, S.M., Malcolm, I.A. (2008). Influence of hydrology and seasonality on DOC exports from three upland catchment. Biogeochemistry, 90, 93-113.

Depetris, P.J., Kempe, S. (1993). Carbon dynamics and sources in the Parana River. Limnol. Oceanogr., 38(2), 382-395.

Erlandsson, M., Buffam, I., Fölster, J., Laudon, H., Temnerud, J., Weyhenmeyer, G.A., Bishop, K. (2008). Thirty-five years of synchrony in the organic matter concentrations of Swedish rivers explained by variation in flow and sulphate. Global Change Biol., 14, 1-8.

European Environment Agency (2008) Waterbase Rivers http://dataservice.eea.europa.eu/dataservice/metadetails.asp?id=984. Accessed 28 August 2008.

Evans, C.D., Monteith, D.T., Cooper, D.M. (2005). Long-term increases in surface water dissolved organic carbon: observations, possible causes and environmental impacts. Environ. Pollut., 137, 55-71.

Fenner, N., Freeman, C., Lock, M.A., Harmens, H., Reynolds, B., Sparks, T. (2007). Interactions between elevated $\mathrm{CO}_{2}$ and warming could amplify DOC exports from peatland catchments. Environ. Sci. Technol., 41, 3146-3152.

Freeman, C., Fenner, N., Ostle, N.J., Kang, H., Dowrick, D.J., Reynolds, B., Lock, M.A., Sleep, D., Hughes, S., Hudson, J. (2004). Export of dissolved organic carbon from peatlands under elevated carbon dioxide levels. $\mathrm{Na}$ ture, 430, 195-198.

Gergel, S.E., Turner, M.G., Kratz, T.K. (1999). Dissolved organic carbon as an indicator of the scale of watershed influence on lakes and rivers. Ecol. Applicat., 9(4), 1377-1390.

Hagedorn, F., Machwitz, M. (2007). Controls of dissolved organic matter leaching from forest litter grown under elevated atmospheric $\mathrm{CO}_{2}$. Soil Biol. Biochem., 39, 1759-1769.

Hejzlar, J., Dubrovsky, M., Buchtele, J., Ružička, M. (2003). The apparent and potential effects of climate change on the inferred concentration of dissolved organic matter in a temperate stream (the Mališe River, South Bohemia). Sci. Total Environ., 310, 143-152.

Hirsh, R.M., Slack, J.R. (1984). A nonparametric trend test for seasonal data with serial dependence. Water Resources Res., 20, 727-732.

Hirsh, R.M., Slack, J.R., Smith, R.A. (1982). Techniques of trend analysis for monthly water quality data. Water Resources Res., 18(1), 107-121.

Hongve, D., Riise, G., Kristiansen, J.F. (2004). Increased colour and organic acid concentrations in Norwegian forest lakes and drinking water - a result of increased precipitation? Aq. Sci., 66, 231-238.

Jaagus, J., Briede, A., Rimkus, E., Remm, K. Precipitation pattern in the Baltic countries under the influence of large-scale atmospheric circulation and local landscape factors. Int. J. Climatol. (in press).

Jager, D.F., Wilmking, M., Kukkonen, J.V.K. (2009). The influence of summer seasonal extremes on dissolved organic carbon export from a boreal peatland catchment: Evidence from one dry and one wet growing season. Sci. Total Environ., 407, 1373-1382.

Klavins, M., Rodinov, V. (2008). Long-term changes of river discharge regime in Latvia. Hydrol. Res., 39(2), 133-141.

Klavins, M., Rodinovs, V., Kokorite, I. (2002). Chemistry of Surface Waters in Latvia. Rīga: LU. 285 pp.

Libiseller, C., Grimvall, A. (2002). Performance of partial Mann-Kendall tests for trend detection in the presence of covariates. Environmetrics, 13, 71-84.

Mattsson, T., Kortelainen, P., Räike, A. (2005). Export of DOM from boreal catchments: Impacts of land use cover and climate. Biogeochemistry, 76, 373-394. 
Pettine, M., Patrolecco, L., Camusso, M., Crescenzio, S. (1998). Transport of carbon and nitrogen to the Northern Adriatic Sea by the Po River. Estuar. Coastal Shelf Sci., 46, 127-142.

Reihan, A., Koltsova, T., Kriauciuniene, J., Lizuma, L., MeilutyteBarauskiene, D. (2007). Changes in water discharges of the Baltic states rivers in the 20th century and its relation to climate change. Nordic Hydrol., 38(4/5), 401-412.

Roulet, N., Moore, T.R. (2006). Browning the waters. Nature, 414(7117), 283-284.

Terauda, E., Nikodemus, O. (2007). Sulphate and nitrate in precipitation and soil water in pine forests in Latvia. Water, Air Soil Pollut. Focus, 7, 77-84.

Vuorenmaa, J., Forsius, M., Mannio, J. (2006). Increasing trends of total organic carbon concentrations in small forest lakes in Finland from 1987 to 2003. Sci. Total Environ., 365, 47-65.
Westerhoff, P., Anning, D. (2000). Concentrations and characteristics of organic carbon in surface water in Arizona: Influence of urbanization. $J$. Hydrol., 236, 202-222.

Worrall, F., Burt, T., Shedden, R. (2003). Long term records of riverine dissolved organic matter. Biogeochemistry, 64, 165-178.

Worrall, F., Burt, T.P. (2007). Trends in DOC concentration in Great Britain. J. Hydrol., 346, 81-92.

Xiang, W., Freeman, C. (2009). Annual variation of temperature sensitivity of soil organic carbon decomposition in North peatlands: Implications for thermal responses of carbon cycling to global warming. Environ. Geol., 58, 499-508.

Yallop, A.R., Clutterbuck, B. (2009). Land management as a factor controlling dissolved organic carbon release from upland peat soils 1: Spatial variation in DOC productivity. Sci. Total Environ., 407, 3803-3813.

Received 9 November 2010

\section{ORGANISKO VIELU KONCENTRĀCIJAS IZMAINAS LATVIJAS UPJU ŪDEN̦OS}

Dabiskas izcelsmes organisko vielu koncentrāciju ūdeņos ietekmē bioloǵisko procesu raksturs un intensitāte upju sateces baseinos, zemes lietojuma raksturs un cilvēka darbības intensitāte, bet šīs vielas spēj ietekmēt daudzas nozīmīgas ūdeņu īpašības, to kvalitāti un izmantošanas iespējas. Kā pierāda veiktais pētījumus, organisko vielu koncentrācijas Latvijas upju ūdeņos ir relatīvi augstas, turklāt gan to koncentrācija, gan arī ūdeņu krāsainība pēdējās desmitgadēs ir ievērojami pieaugusi. Organisko vielu plūsmas ietekmē upju noteces raksturs un tā ilgtermina mainība, kā arī izteikta sezonāli noritošo procesu raksturs. Organisko vielu noteces apjomi gadā ar Latvijas upju ūdeņiem mainās no 1800 līdz $3100 \mathrm{~kg} / \mathrm{km}^{2}$. 